\title{
MOGUĆNOSTI UNAPREĐENJA URBANE BEZBEDNOSTI OTVORENIH PROSTORA KROZ TRANSFORMACIJU NOVOBEOGRADSKIH BLOKOVA
}

\author{
Aleksandra Đukić ${ }^{1}$, Jelena Marić ${ }^{2}$, Tamara Radić ${ }^{3} \quad$ UDK=351.78(1-21)(497.11) \\ https://doi.org/10.18485/fb_ubur.2018.1.ch7 \\ ${ }^{1}$ Arhitektonski fakultet, Univerzitet u Beogradu, adjukic@rcub.bg.ac.rs \\ 2 Arhitektonski fakultet, Univerzitet u Beogradu, jelena.maric1989@yahoo.com \\ ${ }^{3}$ Arhitektonski fakultet, Univerzitet u Beogradu, tamaraoradic@gmail.com
}

\section{Sažetak}

Razvoj teorijske prakse u pogledu identiteta i diverziteta gradova (Lynch, Schulz), odnosno javnih prostora i njihovog uređenja, pokrenuo je novu sferu istraživanja načina na koji različite grupe korisnika doživljavaju ili upotrebljavaju urbani proctor (Kalen, 2007; Danilović, 2010). Bezbednost je jedan od ključnih faktora kvaliteta otvorenih gradskih prostora koji doprinosi njegovoj životnosti i intenzivnom korišćenju (Hillier, 2004). Pored atraktivnog izgleda za život i rad, vitalnosti i životnosti, neophodno je da ovi prostori budu oslobođeni od kriminala i straha, kako bi ih korisnici aktivno, nesmetano i rado koristili (Studija o bezbednosti javnih gradskih prostora u Beogradu: „Sigurniji javni prostor“). Bezbednost zajednice podrazumeva zaštitu ljudi i dobara od svake vrste pretnje i štete, a pozitivni rezultati prevencije kriminala predstavljaju važan aspekt kvaliteta urbanog života svakog gradskog tkiva koje téži održivosti (Danilović, 2010). Međunarodni centar za prevenciju kriminala (The International Centre for the Prevention of Crime) i Svetska zdravstvena organizacija (World Health Organization) bezbednost zajednice posmatraju kao javno dobro.

Savremeni urbanistički koncepti, kao i naučnoistraživačka praksa u oblasti urbanizma i planiranja sve više ističu značaj urbane bezbednosti, odnosno sigurnosti korisnikâ. Tema bezbednosti javnih urbanih prostora aktuelna je na globalnom i lokalnom nivou, a lični osećaj bezbednosti nalazi se na samom vrhu liste zahteva kada je reč o proceni kvaliteta života građana i konkurentnosti među gradovima. Ovaj rad se bavi istraživanjem upravo različitih aspekata urbane bezbednosti na lokalnom nivou, kroz ispitivanje subjektivnog osećaja korisnika i njihove percepcije prostornih elemenata koji utiču na opštu sigurnost. Cilj rada jeste da obezbedi predlog smernica za transformaciju, unapređenje i revitalizaciju otvorenih javnih prostora radi unapređenja opšteg nivoa urbane bezbednosti i stvaranja prostora atraktivnih za život. Povećanje sigurnosti, mobilnosti i bezbednosti korisnika javnih prostora svakako je imperativ savremenog društva, prema konceptu za prevenciju kriminala (CPTED - Crime Prevention Through Environmental Design). Osećaj lične bezbednosti može se definisati kao postojanje sigurnosti i izvesnosti svakodnevnog života (Danilović, 2010, Kyttä, M., Kuoppa, J., Hirvonen, J., Ahmadi, E. \& Tzoulas, T. 2013).

Jačanje lokalnog identiteta građana (Jane Jacobs) jedan je od instrumenata za prevenciju nasilja i vandalizma, naročito na nebezbednim mestima u gradu. Sa druge strane, u koncep- 
tu teritorijalnosti Oskara Njumena [Oscar Newman] potcrtan je značaj teritorijalnosti i činjenice da ljudi brane teritoriju za koju smatraju da im pripada.

U ovom radu pre svega posmatramo urbanu bezbednost na lokalnom nivou, sa aspekta subjektivnog osećaja korisnika prostora, kroz preispitivanje metodâ urbanog dizajna u procesu unapređenja sigurnosti javnih prostora. Za potrebe ovog istraživanja odabrana je lokacija megablokovskih struktura na teritoriji opštine Novi Beograd. Problem koji je prvobitno inicirao istraživanje jesu upravo statistički podaci o stepenu bezbednosti na nivou Beograda. Beograd se ubraja u srednje bezbedne gradove. U periodu 2000-2005. zabeleženo je 2.135 slučajeva samo razbojništva nad ženama (Ministarstvo unutrašnjih poslova). Oko petina svih slučajeva razbojništva odigrala se na opštini Novi Beograd (424 slučaja) (MUP RS, Sekretarijat Beograd). Metodologija istraživanja korišćena u ovom radu participativnog je karaktera, a analiza je rađena na osnovu primene metoda ankete $\mathrm{i}$ intervjua, kao i metoda stručne opservacije i analize trenutnog stanja lokacije.

Za studiju slučaja odabran je prostorni segment jednog od prvih blokova - Bloka 21, s obzirom na jedinstvene tipološke, fizičke i funkcionalne karakteristike ove lokacije. Blok 21 smešten je na „ulazu“ u Novi Beograd, poluotvorenog je tipa i mešovite funkcije, pretežno stambene namene, sa dve obrazovne institucije: OŠ „Jovan Dučić“ i X gimnazije „Mihajlo Pupin“, ali i sa poslovnim i ugostiteljskim objektima. Postupak je korišćen u svrhe identifikacije različitih karakteristika prostora, kao i ponašanja korisnikâ. Ovom metodom uočeni su obrasci ponašanja korisnika, njihovog kretanja i zadržavanja, identifikovane su karakteristične tačke za odmor i stajanje, a ujedno i način korišćenja otvorenih javnih prostora i osnovni elementi koji mogu uticati na smanjenu sigurnost posmatranog područja.

Anketa je rađena po uzoru na anketu sprovedenu u sklopu gorepomenute studije o bezbednosti javnih gradskih prostora u Beogradu. Sprovedena je u periodu 15. 1. - 15. 2. 2017. godine, na teritoriji Bloka 21, sa ukupno 300 ispitanika, što čini više od 3\% ukupnog stanovništva bloka. Prvi deo ankete sastoji se od 7 pitanja, sa ciljem utvrđivanja stepena osećaja lične bezbednosti, na osnovu sopstvenih zapažanja i iskustva. Drugi deo ankete sadrži podatke o prostornim elementima na području Bloka 21 koji imaju direktne i indirektne veze sa bezbednosnim karakteristikama otvorenih prostora.

Strukturu ispitanika čini 187 žena i 113 muškaraca, prosečnih godina 26-40. Najveći procenat ispitanika čini stanovništvo samog bloka ( $70 \%$ - 225 ispitanika), koje koristi otvorene prostore bloka tokom celog dana. Rezultati prvog dela ankete pokazuju da čak $70 \%$ ( 210 ispitanika) smatra kako je njihova lična bezbednost ugrožena na bilo koji način. Ispitanici navode verbalno nasilje, napade, odnosno vandalizam, i druge oblike kriminalnog ponašanja kao glavne izvore osećaja smanjene bezbednosti, dok čak 45\% (135 ispitanika) tvrdi da su lično doživeli neku vrstu neprijatnosti na ovom području.

Većina ispitanika navodi lokacije kao što su neograđena školska dvorišta i dečja igrališta, parking-prostori, neuređeni otvoreni prostori sa neadekvatnim popločanjem, neosvetljeni prostori između zgrada i ulazi u zgrade, označeni kao najmanje bezbedni prostori koje veliki broj ispitanika ( $48 \%$ - 144 subjekata) izbegava u popodnevnim i večernjim časovima. Rezultati drugog dela ankete prikazuju odnos ispitanika prema elementima uređenja otvorenih prostora unutar bloka. Naime, čak 72\% (216 ispitanika) zadovoljno je količinom zelenila, međutim, više od $85 \%$ (255 anketiranih) smatra da su zelene površine i elementi otvo- 
renih prostora unutar bloka neadekvatno uređeni i osvetljeni. Veliki broj stavnovnika navodi kao problem bezbednosti nedovoljan broj parking-mesta $(62 \%-186$ učesnika), kao i manjak različitih aktivnosti i sadržaja unutar samog bloka $(41 \%$ - 123 ispitanika).

Prikazani rezultati prvog dela ankete nesumnjivo svedoče o postojanju problema bezbednosti na nivou posmatranog područja, koje je u korelaciji sa zvaničnim podacima o stepenu kriminala, tj. nasilnog ponašanja na teritoriji opštine Novi Beograd, dok podaci dobijeni iz drugog dela istraživanja služe kao osnova za predlog mogućeg rešenja, odnosno unapređenja i revitalizacije otvorenih javnih prostora sa aspekta urbanog dizajna. Na osnovu metoda istraživanja, kao i rezultatâ ankete, predložene smernice za prevenciju kriminala i unapređenje urbane bezbednosti zahtevaju integralni pristup, formiranje bezbednih javnih prostora, veću atraktivnost i uređenje otvorenih prostora i zelenih površina, unapređenje kvaliteta i pristupačnosti, tj. čitljivosti prostora, radi unapređenja opšteg nivoa urbane bezbednosti i formiranja prostora atraktivnih za život.

Ključne reči: urbana bezbednost, prostorni elementi, otvoreni javni prostori, Novi Beograd, Blok 21

\section{Uvod}

Urbana bezbednost jedna je od primarnih tema u kontekstu savremenih istraživanja kvaliteta, ali i načina korišćenja otvorenih javnih prostora. Razvoj teorijskog aparata u pogledu identiteta i diverziteta gradova (Lynch, Schulz), odnosno javnih prostora i njihovog uređenja, pokrenuo je novu sferu istraživanja načina na koji različite grupe korisnika doživljavaju odnosno upotrebljavaju urbani prostor (Kalen, 2007, Danilović, 2010). Karakter određenog prostora, izgrađene sredine, ali i otvorenih javnih prostora, definisan je umnogome ponašanjem korisnika, odnosno njihovom percepcijom datog prostora (Đukić, 2008). Pored atraktivnog izgleda za život i rad, vitalnosti i životnosti, neophodno je da ovi prostori budu oslobođeni od kriminala i straha, kako bi ih korisnici aktivno, nesmetano i rado koristili (Studija o bezbednosti javnih gradskih prostora u Beogradu: „Sigurniji javni prostor“).

Među ljudskim nagonima potreba za osećajem sigurnosti i bezbednošću zauzima veoma visoko mesto, odmah iza osnovne potrebe za preživljavanjem. Bezbednost zajednice podrazumeva zaštitu ljudi i dobara od svake vrste pretnje i štete, a pozitivni rezultati prevencije kriminala predstavljaju važan aspekt kvaliteta urbanog života svakog gradskog tkiva koje teži održivosti (Danilović, 2010). Imperativ u planiranju otvorenih prostora jeste eliminisanje svih faktora koji doprinose osećaju nesigurnosti, ugroženosti i nebezbednosti korisnika. Osećaj nesigurnosti u javnim gradskim prostorima može imati dve dimenzije - objektivnu i subjektivnu. Objektivna sigurnost podržana je činjeničnim stanjem i realnim okolnostima i događajima zabeleženim u prostoru, dok se subjektivna sigurnost (lični osećaj bezbednosti) karakteriše ličnim osećajem bezbednosti, zasnovanim kako na objektiv- 
nom stanju, tako i na pojedinačnom stepenu prihvatanja i podnošenja, odnosno razumevanja okolnosti u kojima se čovek nalazi.

Ovaj rad teži da istraži nivo kako objektivne tako i subjektivne urbane bezbednosti korisnika na području opštine Novi Beograd, koja je pretrpela znatne transformacije u kontekstu funkcionalnosti uvođenjem prostora, odnosno sadržaja multifunkcionalnog karaktera. Poslednjih godina su izmenjeni identitet i uloga otvorenih javnih prostora unutar megablokova na teritoriji Novog Beograda, u funkciji novih zahteva korisnika i savremenih obrazaca njihovog korišćenja, pa je stoga znatno izmenjen i nivo urbane bezbednosti. U kontekstu metodološkog procesa istraživanja rad je usmeren upravo ka korisnicima otvorenih prostora, kao glavnim stejkholderima.

\subsection{Teorijski i konceptualni okvir istraživanja}

Bezbednost je jedan od ključnih faktora kvaliteta otvorenih gradskih prostora, koji doprinosi njegovoj životnosti i intenzivnom korišćenju (Hillier, 2004). Tema bezbednosti javnih urbanih prostora aktuelna je na globalnom i lokalnom nivou, a lični osećaj bezbednosti nalazi se na samom vrhu liste zahteva kada je reč o proceni kvaliteta života građana i konkurentnosti među gradovima. Međunarodni centar za prevenciju kriminala (The International Centre for the Prevention of Crime) i Svetska zdravstvena organizacija (World Health Organization) bezbednost zajednice posmatraju kao javno dobro.

Razvoj interesovanja urbanističke naučnoistraživačke prakse za temu urbane bezbednosti nesumnjivo proističe iz istraživanja teme značaja identiteta gradskih prostora i načina njihovog korišćenja od strane različitih grupa korisnika. Ovaj rad se bavi istraživanjem upravo različitih aspekata urbane bezbednosti na lokalnom nivou, kroz ispitivanje realnog, kao i subjektivnog osećaja korisnika i njihovu percepciju prostornih elemenata koji utiču na opštu sigurnost u prostoru.

Cilj rada jeste da obezbedi predlog smernica za transformaciju, unapređenje i revitalizaciju otvorenih javnih prostora radi unapređenja opšteg nivoa urbane bezbednosti i formiranja prostora atraktivnih za život. Povećanje sigurnosti, mobilnosti i bezbednosti korisnika javnih prostora svakako je cilj savremenog društva, prema konceptu za prevenciju kriminala (CPTED - Crime Prevention Through Environmental Design). Osećaj lične bezbednosti može se definisati kao postojanje sigurnosti i izvesnosti svakodnevnog života (Danilović, 2010; Kyttä, M., Kuoppa, J., Hirvonen, J., Ahmadi, E. \& Tzoulas, T. 2013). Jačanje lokalnog identiteta građana (Jane Jacobs) jedan je od instrumenata za prevenciju nasilja i vandalizma, naročito na nebezbednim mestima u gradu.

Sa druge strane, u konceptu teritorijalnosti Oscara Newmana potcrtan je značaj teritorijalnosti i činjenice da ljudi brane teritoriju za koju smatraju da im pripada. Određena savremena istraživanja pokazala su da je precepcija bezbednosti kod ljudi uslovljena njihovim prostornim praksama (Häkli, 2009), odnosno da postoji nekoliko faktora koji utiču na lični osećaj bezbednosti, kao što su: pol, starost, socio-ekonomski status, poverenje, narodnost i struktura urbanog tkiva (Alexander, 2012). Teoretičari naglašavaju da je osećaj bezbednosti uslovljen prvenstveno ur- 
banim zadovoljstvom, poverenjem i fizičkim karakteristikama (Jabareen, 2017). Kod javnih otvorenih prostora utvrđeno je da su i fizičke karakteristike prostora tesno povezane sa osećajem zadovoljstva i poverenja kod ljudi. Fokus ovog rada upravo je na otvorenim javnim prostorima.

Javni prostori moraju biti stalno otvoreni za sve stanovnike, kao i za sve posetioce i turiste. Veoma je važno da u njima mogu biti realizovane različite aktivnosti, bilo da su prethodno organizovane, ili su u nekom trenutku spontano nastale. Svaki javni prostor mora biti prohodan, dostupan i čitljiv (Čaldarović, Šarinić, 2008). Svaki urbani prostor mora biti bezbedan.

Boravak u otvorenom gradskom prostoru bitna je potreba - blagotvorni uticaj na ljudsko zdravlje, kako fizičko tako i mentalno, ima posećivanje kvalitetnog otvorenog prostora, koji je prijatan i bezbedan, koji zadovoljava osnovne ljudske potrebe i pruža mogućnosti za nesmetano kretanje, brojne i raznovrsne aktivnosti, koje podstiču socijalizaciju. Potrebe građana u javnom prostoru mogu se svesti na komfor u korišćenju, što može imati najrazličitije pojavne oblike, od potrebe da se korisnici osećaju bezbedno do detalja kao što su, na primer, udobnost parkovskih klupa, ali i mogućnost za relaksaciju tela i uma, što zahteva postojanje prirodnih elemenata, poput zelenila, vode i drugih.

\subsection{Studija slučaja-Blok 21}

$\mathrm{U}$ ovom radu pre svega posmatramo bezbednost sa aspekta korisnika prostora, kroz preispitivanje metoda urbanog dizajna u procesu unapređenja sigurnosti javnih prostora. Za potrebe ovog istraživanja odabrana je lokacija megablokovskih struktura na teritoriji opštine Novi Beograd. Ova opština razvijena je nakon kraja Drugog svetskog rata, na obalama reka Save i Dunava. Opština Novi Beograd građena je po principima modernog grada i elementima proklamovanim u okviru dokumenata kao što su „Atinska povelja“ i drugi. Karakterišu je ortogonalna planska matrica, široki bulevari i geometrizovani urbani blokovi izgrađeni u funkcionalističkom stilu arhitekte Le Corbusier-a. Koncept zajedničkog otvorenog prostora unutar blokovskih struktura prvi put u Srbiji je realizovan na području ove opštine, a upravo ovi prostori su predmet istraživanja rada.

Prvobitna namena ovog područja bila je administrativnog karaktera, u skladu sa principima modernog grada. Međutim, drastičan priliv stanovništva u „,novi““ deo grada uzrokovan ideologijom života u modernom gradu, kao i izgradnja stambenih blokova formirali su novi deo grada sa primarnom i preovladavajućom stambenom funkcijom. Tokom 1960-ih godina prvi stanovnici koji su naselili ovu opštinu došli su iz predela bivše Jugoslavije, većinom iz ruralnog područja, i svoje stambene navike pokušali da primene u urbanom tipu naselja, kao što je Novi Beograd, stvarajući ambijent polururalnog naselja.

Ovakav tip stanovanja, kao i monofunkcionalna izgradnja, doveli su do niza problema u kontekstu kvaliteta života, nedostatka sadržaja i aktivnosti, problema identiteta, outuđenosti, kao i problema bezbednosti. Različite sociološke studije rađene 1970-ih i 1980-ih godina pokazuju da se stanovništvo novobeogradskih 
blokova najviše žalilo na: visoku gustinu naseljenosti, kvalitet izgradnje, visinu objekata, nedostatak sadržaja (Živković, 1975).

Problem koji je prvobitno inicirao istraživanje jesu upravo statistički podaci o nivou bezbednosti na Novom Beogradu. Beograd se ubraja u srednje bezbedne gradove. Na primer: u periodu 2000-2005. zabeleženo je 2.135 slučajeva samo razbojništva nad ženama (Ministarstvo unutrašnjih poslova). Oko petine svih slučajeva razbojništva odigralo se na opštini Novi Beograd (424 slučaja) (MUP RS, Sekretarijat Beograd).

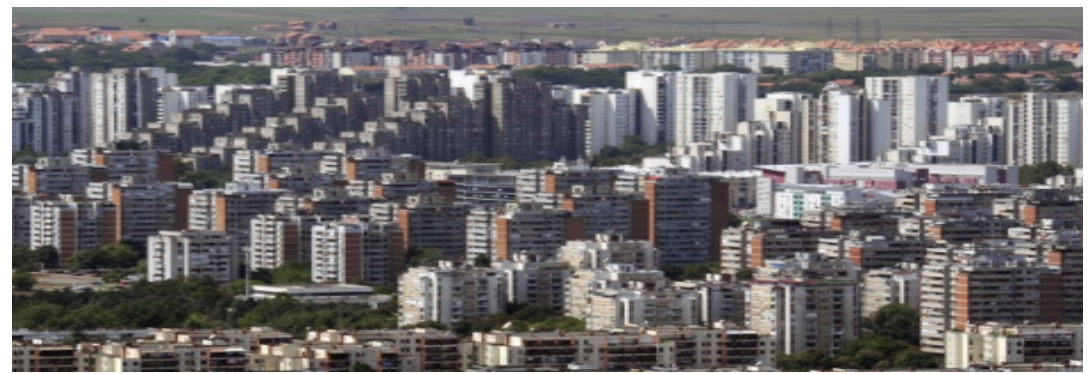

Slika 1 - Novi Beograd

Danas opština Novi Beograd ima preko 300.000 stanovnika i više od 800 objekata za višeporodično stanovanje, sa 90.000 stambenih jedinica. U poslednje dve decenije došlo je do značajnih transformacija megablokovskih struktura: usled velike izgradnje i uvođenja novih sadržaja i namena, karakter opštine se izmenio, kao i odnos privatnog i javnog prostora, ali i način korišćenja i boravka na otvorenim javnim prostorima. Ove transformacije su najuočljivije na primeru Bloka 21, koji je odabran za konkretnu studiju slučaja. Smešten je u istočnom delu opštine na samom ,ulazu“ u Novi Beograd, poluotvorenog je tipa, okružen prometnim saobraćajnicama. Izgrađen je u periodu od 1962. do 1966. godine i bio je gotovo isključivo stambenog karaktera, sa tri različita tipa stambenih jedinica - šest stambenih kula (tzv. „Šest kaplara“), dva stambena bloka i jednim stambenim meandrom, sa preko 2.300 stambenih jedinica.

Danas Blok 21 ima mešovite funkcije, sa obrazovnim institucijama: dva dečja vrtića, OŠ „,Jovan Dučić“ i Deseta (X) gimnazija „Mihajlo Pupin“, brojnim poslovnim i ugostiteljskim objektima, sportskim sadržajima i dečjim igralištima. Za studiju slučaja u radu je analizirana lokacija pomenutog bloka, koja je u poslednje dve decenije doživela značajne tipološke, fizičke i funkcionalne transformacije. Nove funkcije su realizovane, a izgrađene su i nove fizičke strukture.

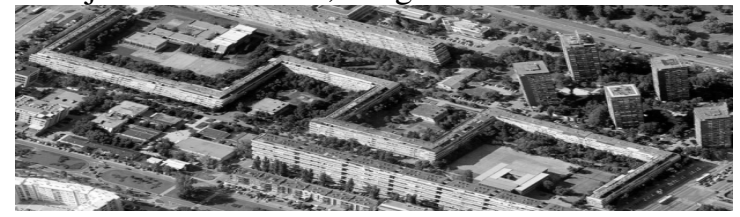

Slika 2 - Blok 21, Novi Beograd 


\section{Metodologija}

Metodologija je u ovom istraživanju formirana sa ciljem da se na što prikladniji način analizira data lokacija sa aspekta prostorno-fizičkih i funkcionalnih karakteristika, ali sa fokusom na mišljenje korisnikâ. Ishod rada usmeren je ka cilju da se revitalizuju i transformišu prostori u unutrašnjosti, ali i obodni delova bloka, radi postizanja višeg stepena bezbednosti žiteljâ, pa samim tim i kvaliteta života stanovništtva na teritoriji megablokovskih struktura. Analiza je rađena na osnovu primene metode ankete i intervjua, kao i metode stručne opservacije i analize trenutnog stanja od strane autora rada. Metodološki proces podeljen je u više koraka:

1. teorijsko i konceptualno istraživanje,

2. sprovođenje ankete i intervjua,

3. prostorna analiza lokacije - metoda opservacije,

4. prikupljanje i interpretacija dobijenih rezultata.

Teorijsko, odnosno konceptualno istraživanje bazirano je na primeni metode analize sadržaja kako primarnih tako i sekundarnih izvora vezanih za temu urbane bezbednosti i umnogome je prikazano u prethodnom poglavlju rada.

Konceptualni okvir rada čini i teorija participativnog planiranja (Forester, 2000; Hoch, 1994; Healey, 1997), gde se participacija, u najširem smislu reči, razume kao proces uključivanja javnosti u postupak donošenja odluka. Participativno, ili kolaborativno planiranje tumači se kao proces zajedničkog promišljanja i rada različitih aktera i interesnih grupa. Kao takvo, participativno planiranje se sprovodi u javnoj sferi i kroz dijalog, odnosno saradnju državnog, privatnog i civilnog sektora u različitim fazama izrade plana (Čolić, 2009). Ono povezuje različite učesnike u ostvarivanju zajedničkih ciljeva. Stoga se može koristiti kao instrument strateškog planiranja lokalnog razvoja. Značajan napredak u primeni participatinih metoda istraživanja empirijskog karaktera uvođenjem lokalnog stanovništva, odnosno ne-eksperata, zabeležen je u poslednje dve decenije (Brown, Kyttä, 2014).

Participativne metode, metode ankete odnosno intervjua, čine okosnicu metodološkog procesa korišćenog u ovom radu. Anketa je rađena po uzoru na onu sprovedenu u sklopu gorepomenute studije o bezbednosti javnih gradskih prostora u Beogradu, kao i istraživanja sprovedenog u prethodnom radu jednog od autora (Đukić, Stajić, 2012). Takođe, pitanja u samoj anketi bazirana su i na istraživanjima rađenim u Ujedinjenom Kraljevstvu, kao što su praktični vodiči za planere, arhitekte i investitore (Safer Places - The Planning System and Crime Prevention, Office of the Deputy Prime Minister, 2004), gde je fokus na sedam faktora upravljanja prostorom: 1. Pristup i kretanje; 2. Struktura; 3. Nadzor; 4. Vlasništvo; 5. Fizička zaštita; 6. Aktivnost; 7. Upravljanje i održavanje.

Anketa je sprovedena u periodu 15.01.-15.02.2017. godine, na teritoriji Bloka 21, sa ukupno 300 ispitanika, što čini više od $3 \%$ ukupnog stanovništva tog bloka. Prvi deo ankete sastoji se od 7 pitanja sa ciljem utvrđivanja stepena osećaja lične bezbednosti, na osnovu sopstvenih zapažanja i iskustva. Drugi deo ankete sadrži podatke o prostornim elementima na području Bloka 21, koji imaju direktne i indirektne veze sa bezbednosnim karakteristikama otvorenih prostora (Slika 3). 


\section{UNIVERZITET U BEOGRADU ARHITEKTONSKI FAKULTET \\ BULEVAR KRALJA ALEKSANDRA 73/I, BEOGRAD}

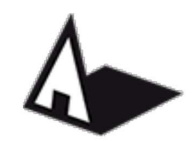

\section{ANKETA O BEZBEDNOSTI NA PODRUČJU BLOKA 21, NOVI BEOGRAD}

A. PODACI O ISPITANIKU

1. POL: muški ženski

2. GODIŠTE: $15-25 \quad 26-40$

3. RADNI ODNOS: student-đak

nezaposlen/a

zaposlen/a

u penziji

41-60 61+

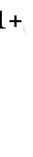

B. PODACI O LIČNOM OSEĆAJU BEZBEDNOSTI

1. Blok 21 posećujete iz sledećih razloga:

- ovde živim

- ovde radim/idem u osnovnu školu-gimnaziju

- provodim vreme u otvorenim prostorima bloka

- u prolazu sam

2. U kom periodu dana provodite vreme u otvorenim prostorima bloka:

- tokom celog dana

- pre podne

- popodne

- uveče

3. Koliko dugo boravite na otvorenim prostorima u bloku:

4. Da li smatrate da je Vaša bezbednost ugrožena na ovim prostorima i kako? $\mathrm{Da} \mathrm{Ne}$

5. Da li se osećate podjednako sigurno u svim delovima dana /svim prostorima bloka? $\mathrm{Da} \mathrm{Ne}$

U kojim delovima dana /na kojim prostirma se osecate manje bezbedno?

6. Da li izbegavate određene javne prostore u bloku iz straha za sopstvenu bezbednost? $\mathrm{Da} \mathrm{Ne}$

7. Da li ste ikada doživeli neku vrstu neprijatnosti na javnom prostoru bloka i koju? $\mathrm{Da} \mathrm{Ne}$

Slika 3 - Segment upitnika primenjenog u istraživanju

Metoda intervjua upotrebljena je ne bi li se prikupile kvalitativne informacije koje dopunjavaju podatke dobijene iz same ankete. Rezultati dobijeni putem metode intervjua korišćeni su pri formiranju razvojnih smernica za unapređenje lokacije.

Metoda opservacije predstavlja jedan od kvalitativnih metoda naučne analize korišćen u svrhe identifikacije različitih karakteristika i korisnika na posmatranom području, izvršen od strane eksperata. Ovom metodom uočeni su obrasci ponašanja korisnika, njihovog kretanja i zadržavanja, identifikovane su karakteristične 
tačke za odmor i stajanje, kao i način upotrebe otvorenih javnih prostora i osnovni elementi koji mogu uticati na smanjenu sigurnost posmatranog područja. Prostorna analiza rađena za potrebe ovog istraživanja ima cilj da dopuni mišljenje korisnika, odnosno da se bolje razumeju prostor, problemi, potencijali i njegovi osobeni elementi, kao i obrasci korišćenja. Analiza je sprovedena od strane autora rada, međutim, bazira se na rezultatima dobijenim iz prethodnih istraživanja vođenih od strane jednog od autora ovog rada (Đukić, Stajić, 2012).

Prostorna analiza obuhvata sledeće elemente: 1) analizu prostornih elemenata (od značaja za aspekt bezbednosti: položaj otvorenih prostora, saobraćajnica i parking-prostora, pravac pešačkog kretanja, stanje zelenih površina, stanje fičičke strukture itd), kao i identifikaciju prostora označenih kao nebezbednih od strane korisnika; i 2) procenu i frekventnost pešačkog kretanja korisnika izražene kroz broj korisnika na karakterističnim saobraćajnicama u sklopu Bloka 21.

\section{Rezultati istraživanja}

U ovom poglavlju prikazani su rezultati dobijeni putem prethodno objašnjenim metodološkim postupkom, odnosno metodama ankete i intervjua, a zatim i metodom opservacije, odnosno analize odabrane lokacije. Rezultati ankete prikazuju mišljenje ukupno 300 ispitanika sa prostora Bloka 21. Strukturu ispitanika čini 187 žena i 113 muškaraca, prosečnih godina starosti između 26 i 40. Najveći procenat ispitanika čini upravo stanovništvo samog bloka (75\% - 225 ispitanika) koje otvorene prostore bloka koristi tokom celog dana.

Rezultati prvog dela ankete pokazuju da čak 70\% (210 subjekata) smatra da je njihova lična bezbednost na neki način ugrožena. Kao glavne izvore osećaja smanjene bezbednosti učesnici ankete navode verbalno nasilje, napade, odnosno vandalizam i druge oblike kriminalnog ponašanja, dok čak 45\% (135 ispitanika) tvrdi da su na ovom području lično doživeli neku vrstu neprijatnosti. Većina ispitanika navodi popodnevne, odnosno večernje časove kao najmanje bezbedne za boravak na otvorenim površinama, dok su mesta kao što su neograđena školska dvorišta i dečja igrališta, parking-prostori, neuređene otvorene površine sa neadekvatnim popločanjem, neosvetljeni prostori između zgrada i ulazi u zgrade navedeni kao najmanje bezbedne zone, koje veliki broj ispitanika ( $48 \%$ - 144 učesnika) izbegava u popodnevnim časovima.

Ishodi drugog dela ankete prikazuju odnos ispitanika prema prostornim elementima unutar bloka. Naime, čak 72\% (216 ispitanika) zadovoljno je količinom zelenila, međutim, više od $85 \%$ (255 subjekata) smatra da su zelene površine i elementi otvorenih prostora unutar bloka neadekvatno uređeni i osvetljeni. Kao problem bezbednosti veliki broj ispitanika navodi nedovoljan broj parking-mesta (62\% - 186 učesnika), kao i manjak različitih aktivnosti i sadržaja unutar samog bloka ( $41 \%$ - 123 ispitanika). Rezultati ankete vezani za predlog mere intervencija za unapređenje bezbednosti, upotpunjeni informacijama dobijenim metodom intervjua, iskorišćeni su u formiranju smernica za unapređenje prikazanih u narednom poglavlju teksta. 
Metodom ekspertske opservacije urađenom od strane autora rada analizirani su prostori u okviru Bloka 21, kao što je predstavljeno na Slici 4. Mapirani su otvoreni javni prostori, prostori uređenih školskih dvorišta i zelenila, zatim glavne saobraćajnice, kao i pravci pešačkog kretanja, dok se na fotografijama vidi stanje objekata, kao i zelenih površina i parking-prostora. Rezultati ove analize prikazni su na Slici 4, a pomažu u boljem razumevanju samog prostora, odnosno prostornih celina i elemenata, kao i njihovog međusobog odnosa, namene površina, načina korišćenja i kretanja korisnika, sa fokusom na mestima koje su korisnici označili kao nebezbedne.

Slika 4. Karta analize prostornih elemenata na teritoriji Bloka 21
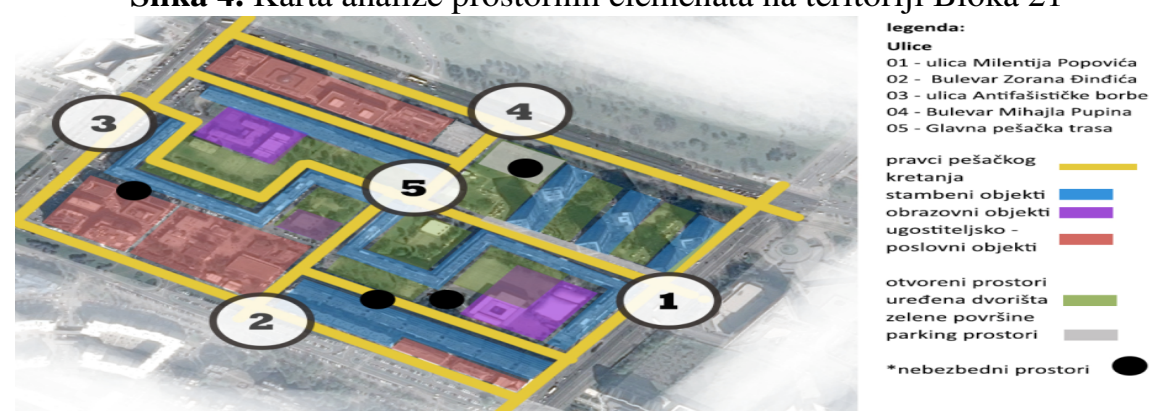

Slika 5. Prikaz prostornih elemenata na teritoriji Bloka 21
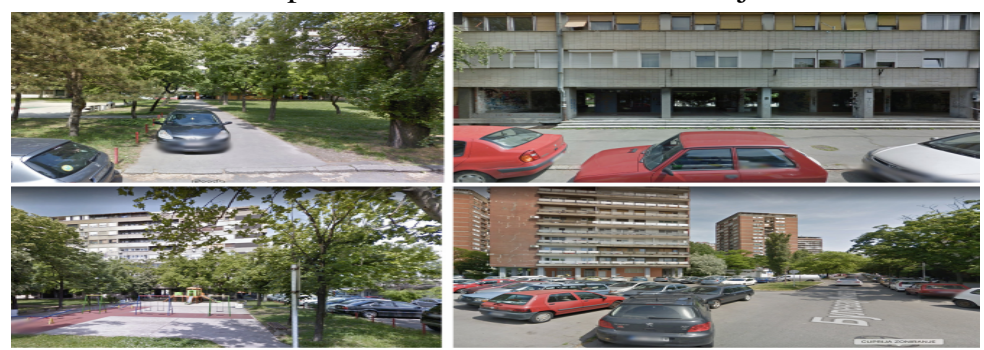

Slika 5 prikazuje kako stanje fizičke strukture i otvorenih prostora, tako i prostore nebezbedne sa aspekta korisnika, kao što su neograđena dečja dvorišta, neuređene zelene površine, nedovoljno osvetljeni ulazi u stambene objekte, kao i neoznačeni parking-prostori.

Intenzitet kretanja prikazan u Tabeli 1 izmeren je na glavnim saobraćajnicama za automobilski i pešački saobraćaj. Merenje je rađeno na naznačenim tačkama sa brojevima 1-5 (Slika 4). Rezultati pokazuju da je kretanje, odnosno broj korisnika, znatno intenzivnije radnim danima nego vikendom, i to u prepodnevnim časovima oko 8.00-9.00, kao i u vreme 15.00-16.00. Većinu korisnika čini upravo radno aktivno stanovništvo, odnosno prolaznici zaposleni u obrazovnim i poslovnim objektima na području Bloka 21 i u neposrednoj okolini. Broj osoba mlađih od 18 godina starosti predstavlja, pored stanovnika bloka, decu koja pohađaju osnovnu i srednju školu. Broj prolaznika znatno je manji u večernjim časovima, kao i na prostoru pešačke staze unutar samog bloka (prostor označen brojem 5, Slika 4). 
Tabela 1. Intenzitet kretanja korisnika na odabranim mestima u okviru Bloka 21

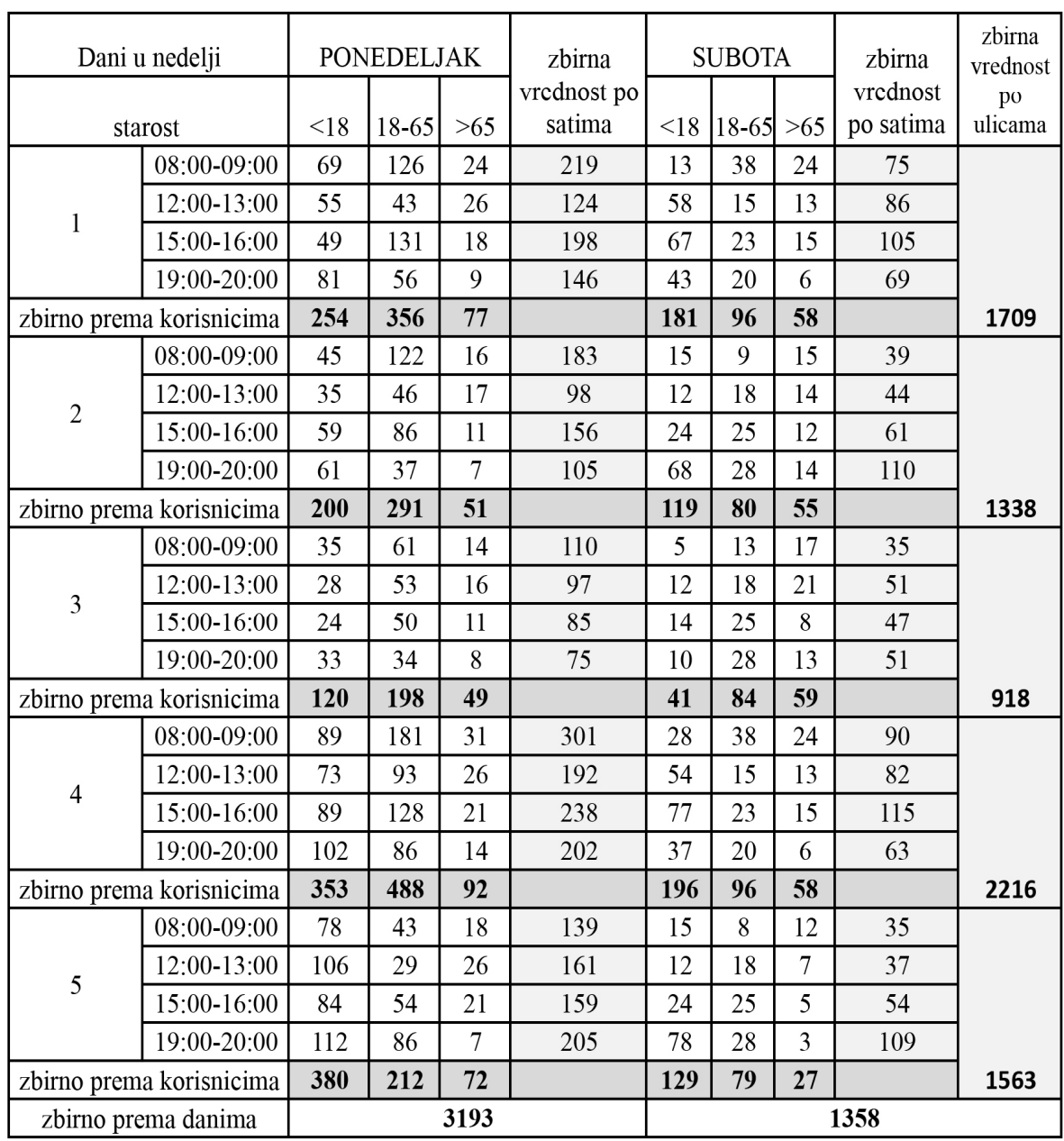

Prema podacima dobijenim od strane korisnika, ali i metodom ekspertske opservacije zadatog područja, stanje je sumarno prikazano kroz primenu $S W O T^{1}$ -analize.

1 Akronim engleskih reči: Strengths, Weaknesses, Opportunities, Threats (što predstavlja: snage, slabosti, prilike, pretnje), a označava tehniku putem koje se uočavaju strategijski izbori dovođenjem u vezu snaga i slabosti sa šansama i pretnjama u eksternom okruženju. Autor ove metode je Albert Hamfri sa Univerziteta Stanford. 
Tabela 2. SWOT-analiza

\begin{tabular}{|c|c|}
\hline Snage (Strengths) & Slabosti (Weaknesses) \\
\hline $\begin{array}{l}\text { - multifunkcionalnost } \\
\text { - postojanje obrazovnih institucija } \\
\text { - mogućnost uvođenja novih namena } \\
\text { i aktivnosti na otvorenim prostorima } \\
\text { - veliki broj korisnika zaposlen na } \\
\text { teritoriji bloka } \\
\text { - visok procenat zelenila }\end{array}$ & $\begin{array}{l}\text { - smanjen lični osećaj bezbednosti } \\
\text { - neobezbeđeni otvoreni prostori i dečja } \\
\text { igrališta i dvorišta } \\
\text { - loša opremljenost otvorenih prostora } \\
\text { - neuređeno zelenilo } \\
\text { - neosvetljeni ulazi } \\
\text { - neoznačeni parking-prostori } \\
\text { - konflikt između pešačkog i } \\
\text { automobilskog saobraćaja } \\
\text { - neobezbeđeni prostori za osobe sa } \\
\text { posebnim potrebama }\end{array}$ \\
\hline $\begin{array}{l}\text { Prilike (Opportunities) } \\
\text { - povoljna pozicija (lokacija) bloka } \\
\text { - veliki broj korisnika na obodnim } \\
\text { saobraćajnicama } \\
\text { - prethodna transformacija bloka, } \\
\text { uz uvođenje novih funkcija }\end{array}$ & $\begin{array}{l}\quad \text { Pretnje (Threats) } \\
\text { - nedostatak javnih sredstava } \\
\text { i neefikasnost javnog sektora } \\
\text { - okruženost prometnim } \\
\text { saobraćajnicama } \\
\text { - zabeležene različite vrste nasilničkog } \\
\text { ponašanja na nivou bloka i šire }\end{array}$ \\
\hline
\end{tabular}

\section{Zaključna razmatranja i smernice za unapređenje}

Glavna korišćena metoda bazirana je na participativnom modelu istraživanja, a u skladu sa prirodom pojma lične bezbednosti, kao glavnog kriterijuma za procenu urbane bezbednosti u gradu. Prikazani rezultati dobijeni putem ankete nesumnjivo svedoče o postojanju problema bezbednosti na nivou posmatranog područja, koji je u korelaciji sa zvaničnim podacima o stepenu kriminala, tj. nasilnog ponašanja na teritoriji opštine Novi Beograd. Takođe, ovi podaci služe i kao podloga za nacrt mogućeg rešenja, odnosno unapređenja ovog prostora sa aspekta urbanog dizajna, a u cilju unapređenja nivoa urbane bezbednosti.

Korišćenje participativnih tehnika prilikom istraživanja daje nam određenu sliku o nivou urbane bezbednosti, međutim, postoji jasna mogućnosti dobijanja subjektivnih rezultata. Uspostavljanje veze između realne/objektivne sigurnosti i ličnog osećaja/subjektivne sigurnosti nameće veliki izazov i stoga dobijeni rezultati moraju biti preispitani pre nego što se uvrste u deo budućih istraživanja, ali i realnih projekata. Međutim, ovo istraživanje svakako ukazuje na generalne strahove građana, odnosno činioce koji su ih proizveli. 
Prevencija kroz urbani dizajn smatra se jednom od osnovnih mera kojom urbanističko planiranje i projektovanje može da doprinese povećanju stepena bezbednosti građana u urbanim gradskim zonama (Danilović Hristić, 2010). Pristup unapređenja bezbednosti proteklih godina sve više je orijentisan na društvo, civilni sektor, odnosno projekte i inicijative bottom-up (odozdo).

$\mathrm{Na}$ osnovu metoda istraživanja, kao i rezultata ankete, predložene smernice za prevenciju kriminala i unapređenje urbane bezbednosti zahtevaju integralni pristup, formiranje bezbednih javnih prostora, veću atraktivnost i uređenje otvorenih prostora i zelenih površina, unapređenje kvaliteta i pristupačnosti, tj. čitljivosti prostora. Sa aspekta planiranja, uvođenje novih namena i aktivnosti, pozicija i orijentacija objekata i otvorenih prostora, proširenje lokalnih ulica, uvođenje gušće ivične gradnje, kao i snaženje mešovitih funkcija, kao što su kultura, usluga, trgovina i slične, u blokovsku strukturu, koja bi rezultovala intenzivnijim korišćenjem u poslepodnevnim i večernjim satima - predstavljaju neke od glavnih smernica za transformaciju blokova.

Preporučene mere intervencije iz domena urbanog dizajna mogu biti sledeće:

- postavljanje adekvatnih ograda i kapija, koje definišu namenu i vlasništvo prostora,

- uvođenje osvetljenja na karakterističnim prostorima za odmor i rekreaciju,

- bolje održavanje i uređenje zelenih površina i elemenata otvorenih prostora: pešačkih i biciklističkih staza, platoa, uličnog mobilijara,

- uvođenje video-nadzora i osvetljenja na ključnim tačkama identifikovanim kao manje bezbedne,

- rešenje konflikta pešačkog i automobilskog saobraćaja te obezbeđenje adekvatnog broja parking-mesta itd.

Da bi se to postiglo, u samom pristupu i planskoj dokumentaciji mora se staviti naglasak na kvalitet planiranja i uređenja prostora, značaj urbane bezbednosti i ličnog osećaja sigurnosti stanovništva. Kreiranjem bezbednijeg i sigurnijeg okruženja direktno utičemo na povećanje urbane bezbednosti, a za akcije predložene ovim istraživanjem potrebno je obezbediti podršku i saradnju struke, lokalne samouprave, građana, MUP-a, nevladinih organizacija i dugih zainteresovanih aktera. Prvi korak svakako jeste afirmisanje uloge građana kao ključnih stejkholdera u ovom procesu, čemu težimo i kroz doprinos ovog istraživanja. 


\section{Literatura}

1. Alexander, C., R. P. (2017) Urban security: Whose security? Everyday responses to, in: V. Ceccato, The urban fabric of crime and fear, New York: Springer, 2012.

2. Brown, G., Kyttä, M. (2014) Key issues and research priorities for public participation GIS (PPIGS): A synthesis based on empirical research in Applied Geography, Amsterdam et al.: Elsevier.

3. Caldarović, O., i Šarinić, J. (2008) First signs of gentrification? Urban regeneration in the transitional society: the case of Croatia, Sociologija i prostor.

4. Danilović Hristić, N. (2010) Urbanističko-arhitektonski elementi za obezbeđenje višeg stepena bezbednosti na javnim gradskim prostorima, neobjavljena doktorska disertacija, odbranjena na Arhitektonskom fakultetu Univerziteta u Beogradu.

5. Danilovic Hristic, N. (2013) Bezbednost urbanih prostora, Beograd: Orion art.

6. Djukic, A. (2008) The Public Space - Transformation and Improvement of Identity, Czasopismo Techniczne, Architektura, z. 2-A/2008 Zeszyt 7 (Rok 105), Kraków: Politechniki Krakowskiej.

7. Djukić, A., Stajić, Lj. (2012) Reconstruction of open public spaces in managing blocks toward safety: case study Block 21, New Belgrade: InDiS.

8. Djukic, A., Vukmirovic, M. (2014) Walking as a Climate Friendly Transportation mode in Urban Environment: Case study Belgrade, IJTTE - International Journal for Trafic and Transport Engineering, Volume 7, Number 4.

9. Jordan, J. (2003) Collective Memory and Locality in Global Cities, In (eds.) Patrice P., Krause L., Global Cities Cinema, Architecture, and Urbanism in a Digital Age, New Brunswick, New Jersey: Rutgers University Press.

10. Fosters, J. (2001) The Deliberative Practitioner - Encouraging Participatory Planning Process. London: The MIT Press.

11. Hoch, C. (1994) What Planners Do? Chicago: APA Planners Press.

12. Jabareen,Y, Eizenberg, E., Zilberman, O. (2017). Conceptualizing urban ontological security: 'Being-in-the-city' and its social and spatial dimensions. Cities, 68.

13. Jordan, J. (2003) Collective Memory and Locality in Global Cities, In (eds.) Patrice P., Krause L., Global Cities Cinema, Architecture, and Urbanism in a Digital Age, New Brunswick, New Jersey: Rutgers University Press.

14. Savić, M. (2000) Novi Beograd - stvaranje identiteta mesta, Izgradnja, Vol. 54, No 11-12.

15. Stajić, Lj. (2007) Bezbednosna kultura kao faktor prevencije kriminaliteta na lokalnom području-sektoru, u: Marinković, D. (prir.): Mesto i uloga policije u prevenciji kriminaliteta: aktuelno stanje i mogućnosti unapređenja, Beograd: Kriminalističko-policijska akademija.

16. Stajić, Lj. (2006) Bezbednosna kultura mladih: kako živeti bezbedno, Beograd: Draganić.

17. Živković, M. (1975) Uvod u sociologiju stanovanja, Beograd: Arhitektonski fakultet. 


\title{
THE POSSIBILITIES OF IMPROVING URBAN SAFETY OF OPEN PUBLIC SPACES: TRANSFORMATION OF THE BLOCK 21 IN NEW BELGRADE
}

\begin{abstract}
Summary
The development of research practice regarding the identity and diversity of cities (Lynch, Schulz), as well as urban design of open public spaces has initiated a new sphere of research regarding the topic of urban safety (Kalen, 2007, Danilović, 2010). Safety is a key factor in the quality of city's outdoors that contributes to its vitality and intensive use (Hillier, 2004). In addition to the urban design and attractiveness of open spaces, it is essential for these areas to be free from crime and fear, in order to ensure active, free and joyful life for its citizens (Study on the safety of urban public space in Belgrade: "Safer public space"). Safety of a community includes the protection of people and goods from any kind of threats and damage, while positive results of crime prevention represent an important aspect of the quality of urban life and sustainable development of city or local community (Danilović, 2010). The International Centre for the Prevention of Crime and World Health Organization regard safety as a public good. The personal sense of safety and well-being is at the top of the priority list when it comes to evaluation of the quality of life and competitiveness among cities. This paper analyses the different aspects of urban safety at the local level, through testing subjective feeling of users and their perception of spatial elements, which affect the general security. The objective of this paper is to provide proposal for the transformation, improvement and revitalization of open public spaces in order to improve the general level of urban safety and to form attractive areas for living.

Increasing the security, mobility and safety of public space is certainly an imperative of a modern society, according to the concept of crime prevention (CPTED - Crime Prevention Through Environmental Design). A sense of personal safety can be defined as the existence of security in everyday life. (Danilović, 2010, Kyttä, M., Kuoppa, J., Hirvonen, J., Ahmadi, E. \& Tzoulas, T. 2013). Strengthening the local identity of citizens (Jane Jacobs) is one of the key instruments for the prevention of violence and vandalism, especially at unsafe places in the city. On the other hand, Oscar Newman emphasizes the importance of territoriality due to the fact that people defend the territory they think they are entitled to.

In this paper security has been primarily observed from the aspect of selected users/stakeholders. The location of mega-block structure in the municipality of New Belgrade was selected as a case study. The problem that had originally initiated this research was statistical information about low safety level in the municipality of New Belgrade. Belgrade is among the medium safe cities. During the period from 2000 to 2005, 2,135 cases of offences against women were recorded (Ministry of the Interior). Around one-fifth of all cases took place in the municipality of New Belgrade (424 cases) (Ministry of the Interior of the Republic of Serbia, The Secretariat in Belgrade, Nataša Danilović Hristić).
\end{abstract}


For the purposes of this paper, the analysis was conducted based on the participative methods of the survey (questionnaire and interview), as well as the method of expert observation and field analysis of one of the first built blocks - Block 21, located at the "entrance" to New Belgrade. It is a semi-open type of a block. It is mainly residential, with public services (educational institutions: Elementary school "Jovan Dučić" and "X high school Mihajlo Pupin"), and several business and commercial facilities. With aforementioned methods, the patterns of user behaviour, their movement and retention, characteristic points for a break and standing were identified, as well as the way of use of open public space and the essential elements that can influence the overall security of the monitored area.

The survey was conducted during the period from 15 January to 15 February 2017, within the territory of the Block 21 , with a total of 300 respondents, which makes more than $3 \%$ of the total population of this Block. The first part of the survey consists of 7 questions in order to determine the degree of personal safety, based on users' observations and experiences. The second part of the survey contains data about spatial elements in the area of Block 21, having direct or indirect links with the safety characteristics of open public space.

The structure of the respondents is: 187 women and 113 men, average age 26-40 years. The largest percentage of respondents is the population of the Block 21 (70\% - 225 respondents), which uses blocks' open spaces during a whole day. The results of the first part of the survey indicate that $70 \%$ of them (210 respondents) consider their personal safety compromised in a certain way. Respondents list verbal violence, attacks, vandalism and other forms of criminal behaviour as the main source of reduced sense of safety, whereas $45 \%$ (135 respondents) claims that they have personally experienced some kind of discomfort in this area. Most respondents have listed unfenced schoolyards and playgrounds, parking places, unregulated open spaces with inadequate tiling, unexposed areas between the buildings and building entrances as the least safe places and a large number of respondents $(48 \%$ - 144 respondents) avoids them during the afternoon and evening. The results of the second part of the survey display a relationship of the respondents to the elements of arrangement of the open spaces within the Block. Specifically, even $72 \%$ of them (216 respondents) are satisfied with the amount of greenery, however more than $85 \%$ of them (255 participants) consider that green areas and elements of open space within the Block are inadequately equipped and illuminated. A large number of respondents refer to insufficient number of parking spaces as a problem of safety (62\% - 186 subjects), and the lack of various activities and the content within the block $(41 \%-123$ respondents).

The presented results of the first part of the survey undoubtedly show the low level of personal safety of the users in the selected area, which is correlated with official data about the level of crime, i.e. violent behaviour in the municipality of New Belgrade. Data collected from the second part of the survey serve as a foundation for proposal of a possible solutions regarding the improvement of this space from the aspect of urban design. Based on obtained results from the survey, and guidelines in crime prevention,improvement of urban security requires an integrated approach, the formation of safe public spaces, higher attractiveness and regulation of open spaces and green areas, quality improvements regarding accessibilityand comfort of the space and better maintenance.

Keywords: urban security, open public spaces, New Belgrade, Block 21 